\title{
Impossible Purities: Blackness, Femininity, and Victorian Culture
}

Jennifer DeVere Brody; Duke University Press, Durham and London, 1998, 334.00 HB, 0-8223-2105-X, £11.95 PB, 0-8223-2120-3

This is both an exhilarating and an infuriating book. DeVere Brody's investigation of the role and function of black women in Victorian conceptualizations of racial and national purity is groundbreaking in its coverage, confident in its assertions, and valuable in its extension of the study of 'Black Atlantic' cultural traffic in the nineteenth century. Describing her critical practice as 'black feminism' (Brody, 1998: 9) DeVere Brody is relentless in her project to uncover the hidden or occluded presence of black femininity. The book pieces together a broad cross-section of Victorian cultural forms structurally and morally dependent on feminized notions of blackness. The material engaged with is fascinating, and the readings fresh, vibrant, and provocative. It takes in canonical Victorian literary texts such as Thackeray's Vanity Fair (1847), popular performances such as minstrelsy, and ends with the key fin de siècle texts, Wells's The Island of Dr Moreau (1896) and Bram Stoker's 'The Lair of the White Worm' (1911). All are opened up in precisely the way called for by Paul Gilroy when he urged critics to 'construct a more pluralistic, post-colonial sense of British culture and national identity'. Orthodox literary and social history, Gilroy argues, has 'long neglected [the] involvement of black slaves and their descendants in the radical history of our country .... Their lives offer invaluable means of seeing how thinking with and through the discourses and the imagery of "race" appears in the core rather than at the fringes of English political life' (Gilroy, 1993: 11, 12).

Impossible Purities responds to this demand with critical and political expediency. It looks centrally at those 'historical connections between England and America' which 'begin to realign national and rhetorical borders' and provides a fascinating survey of the pervasiveness of the 'English interest in "black" Americana' (Brody, 1998: 7, 10). DeVere Brody's contribution to 'Black Atlantic' scholarship is doubly valuable in its awareness that representations of race in the western tradition are never separable from gender and class. Impossible Purities provides important evidence of the "utility of "black" women (mulattas, octoroons, prostitutes) for the (re)production of certain forms of [male] English subjectivity' (Brody, 1998: 7) and locates many examples of what were clearly hugely popular images of intimate connections between 'Englishmen' and black women.

Yet the experience of reading this book is at times maddening and exasperating. I have rarely felt so culturally removed from a feminist academic discourse, so estranged from the material under analysis, and so disconcerted by the book's critical style and method. Oddly, despite my genuine enthusiasm for the type of readings provided in this book, I frequently wanted to question the book's central claims and hypotheses. There are many errors and inconsistencies. For example, 
DeVere Brody claims that in England 'Numerous antislavery societies were established throughout the 1830s and 1840s' (Brody, 1998: 26). Following the formal abolition of slavery in 1833, these societies actually dwindled both in number and membership. That was why it was so hard for abolitionists to campaign effectively against the brutal system of apprenticeship that replaced slavery in the British colonies. Odd phrases such as the 'phenomenon of Queen Victoria' are critically void as well as puzzling. Sensitive and politically complex events are thrown in as possible analogies or references. On 'The Lair of the White Worm' DeVere Brody writes: 'Lady Arabella attempts to lure Mimi into the black hole, the lair of the white worm. Perhaps, in a specifically British reading, the black hole refers to the Black Hole of Calcutta, an infamous prison where many British died in 1746' (Brody, 1998: 175). With no other references to the historical scene of British colonialism in India, the suggestion is tenuous indeed.

But the greatest problem for me is that DeVere Brody's reading practices are bewilderingly top-heavy. Her prose style, far from being dense or obtuse, is passionate and polemical. Yet the priority of the book appears not to be the textual evidence (which is extremely suggestive and challenging), but the display of a critical discourse that is dizzying in its use of spatial metaphors and dazzling in its linguistic agility. This preoccupation with the writer's own language means that the textual examples are all too frequently pushed to the point where their specificity and meaning gets obscured and erased. Let me give an example:

'Who is ever missed in Vanity Fair?'... The answer to this interrogatory is the hybridized Anglo-American mulattaroon, Rhoda Swartz, who is the missing integer in attempts to unify national narratives under a singular sign. Dropped out of rank and 'disappeared', she has now been restored and re-membered, if only for a moment, as part of Victorian culture (Brody, 1998; 45).

With a German-Jewish slave-owner as a father and a silence surrounding her mother, Rhoda Swartz travels to England from St Kitts as a 'rich West India heiress' (Thackeray, 1992: 245). To describe her place of departure as 'Caribbean America' (Brody, 1998: 27) flouts historical accuracy (in 1623 St Kitts was one of the first of the Caribbean islands to be settled by the British as a colony, a 'success' achieved through the murder of some 2,000 indigenous Caribs in 1626 . It remains an independent member of the British Commonwealth). To describe the character as 'Anglo-American' erases St Kitts as a distinctive region in the traffic of Black Atlantic culture and ignores Vanity Fair's fictionalizing of wealth and race as it was supposedly configured in the pre-Abolition British West Indies (the novel is set in the 1810s and 1820s). To further describe Rhoda Swartz as the 'missing integer' imposes too many exogenous definitions on what is, ironically, a character suffering within the novel from enforced identities.

Precisely because much of the material presented in this book is new, or is assessed in distinctively new ways, a lot more plain description and historical 
mapping is needed than DeVere Brody offers. There is little historical positioning of the material, and the term 'Victorian' itself becomes a definitional category with only minimal spatial and temporal meaning. I want to like this book. I want to applaud the risks taken in what is clearly an important feminist intervention. Yet the book has produced a series of transatlantic critical and cultural differences between it and me, which leaves me not quite connecting, and certainly not intimately, with the conclusions and readings that DeVere Brody provides.

Lynnette Turner

\section{references}

Gilroy, P. (1993) The Black Atlantic: Modernity and Double Consciousness, London and New York: Verso.

Thackeray, W.M. (1992) Vanity Fair: a Novel Without a Hero, Oxford: Oxford University Press.

doi:10.1057/palgrave.fr. 9400029

\section{Loving Protection?}

Australian Feminists and Aboriginal Women's Rights 1919-1939

Fiona Paisley; Melbourne University Press, Melbourne, \$32.95 Pbk, ISBN: 0522 849199

As the author rightly observes, this is the first full-length account of proindigenous women's activism between the two world wars in Australia. It highlights a significant moment in both women's and indigenous history. Significant to the former for its emphasis on feminist activism beyond the suffrage campaigns, and significant to the latter for the recovery of a pro-indigenous white reform movement in the 1920 s and 1930s.

This movement was much more significant in the history of Black/White relations than has generally been assumed. Although Paisley concentrates on its feminist manifestations, they were closely associated, as she suggests, with a wider humanitarian campaign for Aboriginal rights. Although marginalized at the time, this movement gained significant momentum as the century wore on. Of course, what made white women's intervention distinctive was their emphasis on the rights of Aboriginal women. This was the first time that the sexual exploitation of Aboriginal women, and its aftermath of disease and mixed race offspring, was publicly raised - some 40 years into the feminist movement itself.

One wonders what the feminist contribution would have been had it not been for Australia's Dominion status and Australian feminists' status as national and international citizens. As Paisley illustrates, their campaign on this subject was worked out within this broader imperial/international framework and, in particular, 